DOI: 10.15290/bsp.2016.20A.en.19

\author{
Andrzej Jackiewicz \\ University of Białystok \\ jackiewicz@uwb.edu.pl
}

\title{
Postal Voting and Voting by Proxy as an Alternative Voting Methods in the Light of the Electoral Code in Poland
}

\begin{abstract}
On 1 August 2011, the Electoral Code, a new act that comprehensively regulates electoral matters in the Republic of Poland, became effective. The article is devoted to the two new mechanisms incorporated in Polish electoral law: postal voting and voting by proxy. The author analyzes them as alternative voting methods in the light of the Electoral Code. Judgments of the Polish Constitutional Tribunal, the Code of Good Practises in Electoral Matters adopted by the Venice Commission and the doctrine of Polish constitutional law, are also taken into consideration. The article focuses on the procedural issues of postal voting and voting by proxy, as well on potential threats to the principle of personal voting and safety of the elections. In the author's opinion, the new alternative voting methods warrant considering Poland as a state that strives to overcome electoral barriers that hinder participation in public life for a large groups of voters. These provisions constitute an important step towards fuller implementation of the principle of universal suffrage and to enable citizens to truly participate in the broadest possible scope.
\end{abstract}

Keywords: voting by proxy, postal voting, elections

Słowa kluczowe: głosowanie przez pełnomocnika, głosowanie korespondencyjne, wybory

\section{Electoral law and voter turnout}

Electoral law of contemporary democratic states is the sphere of public law, which is subject to permanent and most frequently evolutionary modifications, which are dictated by, among other things, changes in the political concept of the state, sometimes temporary needs of political parties, but sometimes they also result from the need to improve the electoral law per se, so as to make it fulfil the functions stemming from the principle of representative democracy.

Some of the contemporary tendencies observed in relation to changes in the electoral law are attempts at coping with the problem of low voter turnout which 
afflicts the European democracies more and more ${ }^{1}$. At the same time, analysis of the causes of this phenomenon and of the methods of its prevention, also within the scope of the so called electoral engineering, has become an important research area. Thus, changes in the electoral law become a response to two categories of causes of low turnout. Firstly, these are the situations which result in the culpable absence, i.e. the cases in which the voter can participate in the election process, but does not consciously choose to do so. This, among other things, follows from the discouragement and lack of confidence of the voters in politics and politicians, the lack of an electoral alternative or the lack of need to get involved in public life in general. Secondly, these are the causes which result in the so called forced absence, i.e. a situation, in which the voter, despite the willingness to vote, cannot do it - they just do not have the physical ability to cast a vote for reasons such as illness, old age, disability, and distance from the voting place. As reported by J. Zbieranek, barriers of such type relate to about $30 \%$ of voters ${ }^{2}$, which shows how important it is to eliminate them in the context of the effective implementation of the principle of universal suffrage. The mechanisms of electoral law with such features are alternative voting methods. The research purpose of this study is the overview of Polish normative solutions in this regard, and the answer to a question how the legislator tries to respond to the phenomenon of the participation crisis.

\section{Alternative voting methods in the Electoral Code - introductory remarks}

On $5^{\text {th }}$ of January 2011, the Act on Electoral Code was passed in Poland. It started to be applicable as at $1^{\text {st }}$ of August $2011^{3}$. The obvious aim of the concept of a single normative act superseding the electoral regulations which had so far been applicable in Poland with regards to parliamentary, presidential, local government and the so called European elections was to harmonise the Polish electoral law ${ }^{4}$, however,

1 J. Blondel, R. Sinnott, P. Svensson, Representation and voter participation, "European Journal of Political Research" 1997, No. 32, pp. 243-244; R.L. Pintor, M. Gratschew (eds.), Voter Turnout Since 1945: Aglobal Report, Stokholm 2002 and A. Ellis, M. Gratschew, J.H. Pmmet, E. Thiessen, Aktywizowanie wyborców. Inicjatywy z różnych państw świata, Warszawa 2008, pp.13-15.

2 J. Zbieranek, Nowe procedury: głosowanie korespondencyjne i przez pełnomocnika, (in:) K. Skotnicki (ed.), Kodeks wyborczy. Wstępna ocena, Warszawa 2011, pp. 37-40. See also: A. Błaszczak, J. Zbieranek, Gwarancje korzystania z czynnego prawa wyborczego przez osoby starsze i osoby z niepełnosprawnościami, "Biuletyn RPO. Źródła" 2012, No. 8, pp. 9-10, where authors provide demografic data presenting the scale of significance of various physical barriers hindering or even preventing voting.

3 Dz.U. z 2011 r. Nr 21, poz.112 z późn. zm [Journal of Laws of 2011 No. 21 item 112 as amended].

4 On the issue of unification of electoral law and on legislative works on Electoral Code see: K. Skotnicki, Przebieg prac nad Kodeksem wyborczym, (in:) K. Skotnicki (ed.), Kodeks wyborczy. Wstępna ocena, Warszawa 2011, pp. 11-35. 
Postal Voting and Voting by Proxy as an Alternative Voting Methods in the Light...

on this occasion, cautious reforms of the electoral law were undertaken, also with regards to the new options for participation of citizens in the public life in the form of alternative voting methods. In a democratic state, one can almost talk about 'the obligation of the legislator to create a real opportunity for everyone who is eligible for voting, to participate in elections'5, which, in the light of the standards observed in other democratic states which evolve in the same direction, caused the creation of such legal framework, which enabled the alternative voting to be almost unavoidable.

The Polish Electoral Code stipulates two alternative voting methods: postal voting and proxy voting. They are applicable in almost all the election procedures (with exclusions which will be discussed further in the text).

Both solutions are related to deviations from the principle of voting in person, in the situations in which the strict requirement to cast a vote in person at a polling station would cause either the actual impossibility of voting or significant hindrance which would practically discourage the voter from participation in elections. As explained by G. Kryszeń, the requirement of voting in person at the polling station is not strictly observed in a large number of states, and the exceptions to it are made mainly in order to increase the voter turnout, and thus to strengthen the principle of universal suffrage ${ }^{6}$. However, an observation must be made that any alternative voting methods are understood as alternative in relation to the traditional personal voting at the polling station. At the same time, it is necessary to notice the difference between the issue of personal voting at the polling station and the issue of personal voting understood as the independent and autonomous performance of activities related to casting a vote. Such an understanding of the personal voting is assumed in the Electoral Code, which acknowledges in Article $38 \$ 2$ that postal voting constitutes a form of personal voting. In the case of the proxy voting, the act does not provide for any similar regulation.

\section{Postal voting according to the Electoral Code}

The above-mentioned postal voting is a solution which the Electoral Code has introduced for the first time into the Polish electoral law ${ }^{7}$.This is a voting method which arouses controversy, but is permissible in member states of the Council of Europe $^{8}$. It is provided for in the electoral laws of Australia, Bangladesh, Bosnia,

$5 \quad$ M. Chmaj, W. Skrzydło, System wyborczy w Rzeczypospolitej Polskiej, Warszawa 2011, p. 39.

6 G. Kryszeń, Standardy prawne wolnych wyborów parlamentarnych, Białystok 2007, p. 222.

7 The first attempt at introducing a mechanism forpostal voting to Poland took place during works on the voting system to the European Parliament at the turn of 2002 and 2003, see: Zbieranek, Nowe procedury..., op. cit., p. 48-49, pp. 51-56.

8 The Venice Commission - in Code of good practices inelectoral matters includes this voting method, making however subjective reservations, as well as conected to relability of postal system - Code of good practices in electoral matters. Guidelines and explanatory reports, Adopted by 
Estonia, Finland, Greece, Spain, the Netherlands, India, Ireland, Iceland, Japan, Canada, South Korea, Canada, Lesotho, Germany, New Zealand, Pakistan, Portugal, Federal Republic of Germany, Slovenia, the United States, Switzerland, Sweden, Great Britain, Lithuania, Latvia and the Philippines. In the great majority of these states, the postal voting was narrowed down to a group of people remaining beyond the state borders, and only in few of them, this right was vested also in the citizens on their territories, whereby in some of them, all voters were taken into account and in some others, only their certain categories, e.g. the disabled people or the elderly people ${ }^{9}$.

The amendment to the Electoral Code of 11 July $2014^{10}$ extended the possibility of voting by post, providing such an option to each voter. Before that amendment, the Polish Electoral Code stipulated that such a voting method will only be available to the disabled voters and to voters who cast their vote in polling wards established abroad. At present, the Electoral Code regulates this type of voting in Section I, chapter $6 \mathrm{a}$ (previously, the relevant provisions were included in Section I, chapters 7a and 8). The limitation of the range of the postal voting is the exclusion of this method in local government elections, whereby the disabled voters ${ }^{11}$ may vote by post also during these elections. Furthermore, the postal voting is excluded in the case of voting in polling wards established in a health care institution, nursing home, penal institution and custody suite, student dormitory and in polling wards established on Polish marine ships, and also in the case of delegation of the right to vote by the disabled voter.

the Venice Commission at its $52^{\text {nd }}$ session (Venice, 18-19 October 2002), Opinion no. 190/2002, CDL-AD (2002) 23 rev, p. 21; The Venice Commission to correspondence voting devotes also Report on the Compatibility of Remote Voting and Electronic Voting with the Standards of The Council of Europe. Adopted by the Venice Commission at its $58^{\text {th }}$ Plenary Session (Venice, 12-13 March 2004) on the basis of a contribution by Mr Christoph Grabenwarter (substitute member, Austria), Studyno. 260/2003, CDL-AD(2004)012. Both documents available at: www.venice.coe. int (accessed on: 12.06.2014)

9 Enumeration of states, in electoral law of which provides for the postal voting was prepared on the basis of: Z. Szabo, Distance voting, Raport sporządzonego na potrzeby Zgromadzenia Parlamentarnego Rady Europy, Doc. No. 11434 of 12 July 2007, Parliamentary Assembly Working Papers, Ordinary Session 21-25 January 2008, vol.1, p. 90; G. Kryszeń, Standardy prawne..., op. cit., pp. 224-225; M. Qvortrup, Absentee Voting in a Comparative Perspective: A Preliminary Assessment of the Experiences with Postal Voting, Submissionfor The Joint Standing Committee on Electoral Matters, Australian Federal Parliament, text available at Aca- demia.edu (accessed on: 12.06.2014). J. Zbieranek, Nowe procedury..., op. cit., pp. 46-48; J. Zbieranek., Alternatywne procedury głosowania w Polsce na tle państw Unii Europejskiej, "Biuro Analiz Sejmowych" 2011, No. 3, pp. 99-102.

10 Ustawa z dnia 11 lipca 2014r. o zmianie ustawy - Kodeks wyborczy oraz niektórych innych ustaw (Dz.U. z 2014 r. poz. 1072) [Journal of Laws of 2014 item 1072].

11 With significant or intermediate level of disability within the meaning of an act of 27 August 1997 on Vocational and Social Rehabilitation and Employment of Persons with Disabilities (Dz.U. z 2011 r. Nr 127, poz. 721, z późn. zm.) [Journal of Laws of 2011 No. 127 item 721 as amended]. 
Postal Voting and Voting by Proxy as an Alternative Voting Methods in the Light...

In the case of voting in the home country, the voter notifies the village mayor (city mayor or city president) of the intention to vote by post, and if voting abroad is considered - the territorially competent consul must be notified by the $15^{\text {th }}$ day before the date of elections. After the formal validation of the application, the voter is entered into the suitable list of voters in the area of the commune where the voter is entered into the register of voters. In the case of the voting by post abroad, the voter is entered into the list of voters in the polling ward competent for the precinct electoral commission indicated by the regulation of the minister of foreign affairs, wherein at least one precinct electoral commission competent for the purposes of the voting by post, is indicated within the confines of the territorial jurisdiction of each consul.

The voter who declared the intention to vote by post in their country receives the election package from the commune office no later than 7 days before the date of elections. In the case of a voter who expressed their intention to vote by post abroad, it is the competent consul who is responsible for the sending of the election package, which should be done immediately after receiving a ballot paper from the competent election commission, however no later than 10 days before the election date.

Pursuant to Article $53 \mathrm{~g} \$ 1$. of the Electoral Code, the election package includes:

1) a return envelope;

2) a ballot paper or papers;

3) an envelope for the ballot paper or papers;

4) postal voting instructions;

5) an overlay or overlays on the ballot papers made in the Braille alphabet - if the voter requested them;

6) declaration on the personal voting by secret ballot.

The voter who votes by post, puts the completed ballot paper into the ballot paper envelope, which they seal, and then inserts this envelope into the return envelope including the signed declaration and sends it to the relevant precinct election committee ${ }^{12}$, in the case of voting in their home country, and in the case of voting abroad - at their own expense, to the address of the competent consul ${ }^{13}$. The envelopes for the ballot papers removed from the return envelopes delivered to the precinct election committee are thrown into the ballot box. In the case of voting by post abroad, the consul delivers the return envelopes received by the time of completion of the voting, to the relevant precinct election committee. This causes the ballot papers to reach the relevant ballot box a bit later.

12 A voter can hand over a returnable envelope to a representative of operator designated within the meaning of an act of 23 November 2012 - Postal law (Dz.U. z 2012 r., poz. 1529) [Journal of Laws of 2012 item 1529]. It is also possible to cast a vote before the day of election, as a voter can personally deliver the returnable envelope when voting in a country - to a proper municipal office, when voting abroad - to a proper consul.

Return envelopes, if voting in a country, are free from postal charges. 
The Polish solutions for postal voting must be considered modern. The legislator broadened the circle of people who can vote this way, making the use of this voting method possible by all voters. However, it will only be evident in practice during the following elections whether the mechanism enjoys popularity ${ }^{14}$, or whether it has not become a subject of abuse, as this voting method also entails certain risks. The said risks can be related to, among others, the danger of not maintaining the secrecy of voting - thus creating conditions for the potential phenomenon of 'vote trading' or simply exerting pressure on the voters (e.g. within a given household), and the danger of forgeries, postal system imperfection or problems with meeting the formal requirements of such voting ${ }^{15}$. Despite these doubts the Venice Commissionin the above-mentioned code of good practice in electoral matters takes this voting method into consideration, pointing, however to subjective reservations as well as reservations related to the reliability of the postal system.

The Polish legislator considers the unauthorised opening or destruction of the election package or sealed envelope to be particularly dangerous for the postal voting and provides for a penal provision for such an act (Article 513a), which imposes a fine.

Just as is the case with proxy voting, the opinion on the postal voting was expressed by the Constitutional Tribunal in the already quoted judgement, claiming that the postal voting does not infringe upon the principle of voting secrecy and the standards of integrity of a democratic state, positively assessing this voting method as an optional form of voting that implements the principle of universal suffrage ${ }^{16}$.

\section{Proxy voting pursuant to the Electoral Code}

A relatively new solution in the Polish electoral law is the second alternative voting method provided for by the Electoral Code - voting by proxy ${ }^{17}$. As reported by G. Kryszeń, such a method is available in the electoral law of such states as: Belgium,

In parliamentary elections in 2001, 807 persons in the country took advantage of correspondence voting, whereas only some of them did it effectively (647 persons) - see: A. Błaszczak, J. Zbieranek, Gwarancje korzystania..., op. cit., pp. 69-70.

15 On advantages and disadvantages of correspondence voting writes D.P. Bannon, Electoral participation and Non Voter Segmentation, (in:) W.W. Wymer Jr, J. Lees - Marshment (eds.), Current Issues in Political Marketing, Binghampton 2006, pp. 114-116, see also M.Qvortrup, First past the Postman: voting by Mail In Comparative Perspective, “The Political Quarterly" 2005, vol. 76, No. 3, pp. 416-418, where we can also find remarkes on a genesis of correspondence voting and effects of introducing this type of voting inter alia to United Kingdom, Australia and New Zeland.

16 Judgment of the Constitutional Tribunal of 20 July 2011, K 9/11.

17 When works on Electoral Code were taking place, proxy votingwas introduced to the voting system binding in presidential and self-government elections, on the basis of which elections in 2010 took place. At that time, several thousand voters, the elderly or with disabilities, took 
Postal Voting and Voting by Proxy as an Alternative Voting Methods in the Light...

France, Ghana, Georgia, Guiana, Spain, The Netherlands, Latvia, Mali, Sweden and Great Britain, whereby the approach to this mechanism differs as regards the group of people entitled to grant a proxy and to accept it, the number of possible proxies which can be accepted by one voter, the varying period of validity of a proxy and the method of its granting ${ }^{18}$.

The Polish Act deals with the proxy voting in Section I, chapter $7^{19}$. Also in the Polish version, this is a solution which is limited in its nature with regards to the subjects it covers -as pursuant to Article 54, this voting method may only be taken advantage of by a disabled voter with a significant or moderate degree of disability ${ }^{20}$ or a voter who is 75 years old on the election day at the latest. Only such a person may delegate their rights to vote. Furthermore, the legislator decided that such a voting method is excluded in the case of voting in separate polling wards and in polling wards established abroad and on Polish marine ships, and also if the disabled voter declares the intention of postal voting.

The regulations of the Electoral Code specify who can act as a proxy holder and how the procedure of granting and withdrawing of a proxy should look. Pursuant toArticle55 of the Act, the proxy holder can be a person entered into the register of voters in the same commune as the person who delegates the right to vote. The Code also rightly allows for a situation in which the right to vote is delegated to a person who has a certificate regarding the voting right(if the regulations, especially those concerning the given elections provide for a possibility of obtaining such a certificate), thus allowing for e.g. the empowering of a family member who resides in a different commune.The code enables the acceptance of the proxy from one voter only - an exception is provided for in the case of listed categories of people - it is additionally possible to be a proxy for two persons of which one is a family member in adrogation

advantage of the procedure of voting by proxy in both elections. See: A. Błaszczak, J. Zbieranek, Gwarancje korzystania..., op. cit., p. 22.

18 G. Kryszeń, Standardyprawne..., op. cit. ,p. 223, about differences writes J. Zbieranek, Nowe procedury..., op. cit., pp. 42-44, writes J. Zbieranek, Alternatywne procedury..., op. cit., p. 9698. See also: A. Krasnowolski, Głosowanie przez pełnomocnika, głosowanie antycypowane i głosowanie korespondencyjne w krajach europejskich i Kanadzie, Warszawa 2006, p. 10 et seq.; K. Skotnicki, Zasada powszechności w prawie wyborczym. Zagadnienia teorii i praktyki, Łódź 2000 , p. 263 et seq.

19 The idea of proxy voting, as the idea of postal voting, was one of few arguable areas during works of the extraordinary Sejm commission taking care of bills - see K. Skotnicki, Przebieg prac..., op. cit., p. 25.

20 Within the meaning of an act of 27 August 1997on Vocational and Social Rehabilitation and Employment of Persons with Disabilities (Dz.U. z 2011 r. Nr 127, poz. 721) [Journal of Laws of 2011 No. 127 item 721]. The scope of persons eligible to take advantage of this voting method was a subject to controversy during works on Electoral Code, as well as even after its entry into force see J. Zbieranek, Nowe procedury..., op. cit., p. 56. 
or guardianship relation ${ }^{21}$. This is to prevent the use of this mechanism contrary to the intentions of the legislator, e.g. by paid collection of proxies to vote ${ }^{22}$.

Because of the safety of elections, the procedure of proxy voting per se is formalised. On the ninth day before the election date at the latest, the voter applies for drawing up of a proxy act to the competent commune head, providing the relevant data regarding the principal, including the documents which identify them as person eligible for voting in this manner and the documents which certify the ability of a given person to be the proxy. The proxy act is established before the commune head or other officer authorised by them at the place of residence of the voter or at a different place in the area of the commune requested by the voter.

In as much as the institution of proxy voting per se is advantageous from the point of view of the principle of universal suffrage, it must be borne in mind that it rouses controversy from the point of view of other electoral principles. Taking into account the voices of doctrine, G. Kryszen points out that what raises doubts is its

compliance with the principle of direct elections and the principle of voting secrecy ${ }^{23}$, which leads him to the conclusion that proxy voting is contrary to 'fundamental requirements of free elections ${ }^{24}$. The essential risk for the concept of proxy voting is the situation in which the proxy holder casts a vote in accordance with their own views,and not according to the will of the voter that delegates the right to vote ${ }^{25}$. An opinion about the doubts resulting from the proxy voting was also expressed by the Constitutional Tribunal which welcomed this institution as an additional guarantee for the use of the voting rights by citizens. The Tribunal rejected the arguments that the proxy voting is contrary to the principle of direct voting, arguing that this principle means that the voting act is a one-step process which does not create an obligation to vote in person ${ }^{26}$.

21 A proxy cannot be a person who is a member of district committee competent for the voting district of a person granting a proxy vote, men of confidence, as well as candidates in the subject elections.

22 The Electoral Code in Article $60 \$ 2$ literally prohibits a proxy from collecting any charges from a person granting a proxy for voting in hero $r$ his name, and in Article $60 \$ 3$ prohibits granting a voting proxy for any financial or personal benefit.

23 J. Mordwiłko, W sprawie ustanowienia z polskim prawie wyborczym instytucji pełnomocnika oraz możliwości głosowania drogą pocztową (głosowania korespondencyjnego), "Przegląd Sejmowy" 2001, No. 1, p. 67-71, where author presents short review of the doctrine views on the content of the principle of direct elections and doubts connected to the issue of casting vote in person.

24 G. Kryszeń, Standardy prawne..., op. cit., p. 223.

25 K. Skotnicki, Zasada powszechności..., op. cit., p. 267.

26 Judgment of the Constitutional Tribunal of 20 July 2011, K 9/11. Additionally, the Tribunal dismissed the charge of violation of the principle of equality in formal regard, using the argument that a proxy casts a vote in the name of a voter, and not in his name. Therefore, she or he does not have two votes, but one her or his own (as a voter) and one vote executed in the name of another voter. 
Postal Voting and Voting by Proxy as an Alternative Voting Methods in the Light...

Taking into account the views of the doctrine which indicate the risks related to the proxy voting, the Polish normative model for this voting mechanism, limited in terms of the group of people which it covers and also relatively formalised, seems to be a solution prudent enough that being treated as an exception to the rule of personal voting, it fits in with the principles of a democratic state. Nevertheless, only the practice during several subsequent elections will show whether this mechanism is not a subject of abuse.

It is worth noticing that the Electoral Code provides for penal provisions related to the institution of the proxy voting, which are additionally supposed to prevent the pathological behaviour oriented towards gaining benefits, related to giving a proxy both on the part of the person who grants the proxy and the proxy holder per se. On the one hand, pursuant to article 511, he who collects a charge from the person that delegates the right to vote on his behalf - is subject to a fine, and pursuant Article 512 , he who delegates his voting right for a material or personal benefit - is subject to imprisonment or fine ${ }^{27}$.

\section{Conclusions}

The solutions of the Polish Electoral Code presented above undoubtedly help to implement the principle of universal suffrage, which, per se, determines the group of people that represent the electorate - however, in the context of the issue of participation, it is essential to treat the proxy voting or postal voting as the guarantees of this principle, allowing as large a part of this electorate to participate in elections. The elimination of the above-mentioned risks should cause the further development of the concept of alternative voting methods, which is proven by the amendment to the Electoral Code which concerns the postal voting. The introduction of these methods and the progress in their implementation also create the grounds for a discussion of the future of e-voting in Poland. However, various problems which accompanied the local government elections in the year 2014 undoubtedly did not contribute to the creation of a good 'political climate' for the discussion of the introduction of $e$-voting in Poland and for further progress in the field of alternative voting methods.

As well as the solutions provided for by the Electoral Code, which have been mentioned above, attention must also be paid to aspects related to dissemination of information. According to A. Błaszczak and J. Zbieranek, the information campaign regarding new solutions before the parliamentary elections which were held in the year 2011 was fairly limited and rather late. It must be noted here that the Electoral Code per se imposes a number of information responsibilities on the local governments, State Election Committee and precinct election committees, referring

27 See: A. Błaszczak, J. Zbieranek, Gwarancje korzystania..., op. cit., pp. 51-54. The same authors write more on potential of informative factor and postulates in this regard (pp. 84-93). 
particularly to the disabled. (see Chapter 5a of the Electoral Code). Obviously, making the voters aware of new solutions will not have an immediate effect, and the popularisation of knowledge in this respect requires appropriate information actions taken by the state authorities.

The solutions included in the Electoral Code, without any doubt, constitute an important step forward towards better implementation of the principle of universal suffrage. Both the solutions established in the Polish electoral law and the new mechanisms of alternative voting, in the opinion of the author, allow for making Poland a part of the group of states whose aim is to overcome barriers regarding elections. Both the normative solutions and the judgement of the Constitutional Tribunal prove the importance given to the principle of universal suffrage, even accepting the risks posed by the optional voting methods.

\section{BIBLIOGRAPHY}

Bannon D.P., Electoral participation and Non VoterSegmentation, (in:) W.W. Wymer Jr, J. Lees - Marshment (eds.), Current Issues in Political Marketing, Binghampton 2006

Blondel J., Sinnott R., Svensson P., Representation and voter participation, European Journal of Political Research 1997, No. 32

Błaszczak A., Zbieranek J., Gwarancje korzystania z czynnego prawa wyborczego przez osoby starsze i osoby z niepełnosprawnościami, Biuletyn RPO. Źródła 2012, No. 8

Chmaj M., Skrzydło W., System wyborczy w Rzeczypospolitej Polskiej, Warszawa 2011

Ellis A., Gratschew M., Pmmet J.H., Thiessen E., Aktywizowanie wyborców. Inicjatywy z różnych państw świata, Warszawa 2008

Krasnowolski A., Głosowanie przez pełnomocnika, głosowanie antycypowane i głosowanie korespondencyjne w krajach europejskich i Kanadzie, Warszawa 2006

Kryszeń G., Standardy prawne wolnych wyborów parlamentarnych, Białystok 2007

Mordwiłko J., W sprawie ustanowienia z polskim prawie wyborczym instytucji pełnomocnika oraz możliwości głosowania drogą pocztową (głosowania korespondencyjnego), Przegląd Sejmowy 2001, No. 1

Pintor R.L., Gratschew M. (esd.), Voter Turnout Since 1945: A global Report, Stokholm 2002 Skotnicki K., Przebieg prac nad Kodeksem wyborczym, (in:) K. Skotnicki (ed.) Kodeks wyborczy. Wstępna ocena, Warszawa 2011

Szabo Z., Distance voting, Raport sporządzony na potrzeby Zgromadzenia Parlamentarnego Rady Europy, Doc. nr 11434 z 12 lipca 2007, Parliamentary Assembly Working Papers, Ordinary Session 21-25 January 2008, vol. 1

Qvortrup M., First past the Postman: voting by Mail In Comparative Perspective, The Political Quarterly 2005 , vol. 76 , No. 3

Qvortrup M., Absentee Voting in a Comparative Perspective: A Preliminary Assessment of the Experiences with Postal Voting, Submission for The Joint Standing Committee on Electoral Matters, Australian Federal Parliament, text available atacademia.edu 
Postal Voting and Voting by Proxy as an Alternative Voting Methods in the Light...

Zbieranek J., Nowe procedury: głosowanie korespondencyjne i przez pełnomocnika, (in:) K. Skotnicki (ed.) Kodeks wyborczy. Wstępna ocena, Warszawa 2011

Zbieranek J., Alternatywne procedury głosowania w Polsce na tle państw Unii Europejskiej, Biuro Analiz Sejmowych 2011, No. 3 